British Diplomacy and US Hegemony in Cuba, 1898-1964 
This page intentionally left blank 


\section{British Diplomacy and US Hegemony in Cuba, 1898-1964}

\section{Christopher Hull}

Lecturer, Department of Spanish, Portuguese and Latin

American Studies, University of Nottingham 


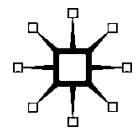

(c) Christopher Hull 2013

Softcover reprint of the hardcover 1st edition 2013 978-0-230-29544-5

All rights reserved. No reproduction, copy or transmission of this publication may be made without written permission.

No portion of this publication may be reproduced, copied or transmitted save with written permission or in accordance with the provisions of the Copyright, Designs and Patents Act 1988, or under the terms of any licence permitting limited copying issued by the Copyright Licensing Agency, Saffron House, 6-10 Kirby Street, London EC1N 8TS.

Any person who does any unauthorized act in relation to this publication may be liable to criminal prosecution and civil claims for damages.

The author has asserted his right to be identified as the author of this work in accordance with the Copyright, Designs and Patents Act 1988.

First published 2013 by

PALGRAVE MACMILLAN

Palgrave Macmillan in the UK is an imprint of Macmillan Publishers Limited, registered in England, company number 785998, of Houndmills, Basingstoke, Hampshire RG21 6XS.

Palgrave Macmillan in the US is a division of St Martin's Press LLC, 175 Fifth Avenue, New York, NY 10010.

Palgrave Macmillan is the global academic imprint of the above companies and has companies and representatives throughout the world.

Palgrave ${ }^{\circledR}$ and Macmillan ${ }^{\circledR}$ are registered trademarks in the United States, the United Kingdom, Europe and other countries.

ISBN 978-1-349-33352-3

ISBN 978-1-137-30176-5 (eBook)

DOI 10.1057/9781137301765

This book is printed on paper suitable for recycling and made from fully managed and sustained forest sources. Logging, pulping and manufacturing processes are expected to conform to the environmental regulations of the country of origin.

A catalogue record for this book is available from the British Library.

A catalog record for this book is available from the Library of Congress.

$\begin{array}{llllllllll}10 & 9 & 8 & 7 & 6 & 5 & 4 & 3 & 2 & 1\end{array}$

$\begin{array}{llllllllll}22 & 21 & 20 & 19 & 18 & 17 & 16 & 15 & 14 & 13\end{array}$ 


\section{Contents}

List of Tables and Illustration vi

Acknowledgements vii

List of Abbreviations $\quad$ ix

$\begin{array}{lr}\text { Introduction } & 1\end{array}$

1 Perfidious Albion? Britain and Cuba before $1898 \quad 15$

2 Uncle Sam versus the British Lion 34

3 The First World War to Boom and Bust 55

4 Beyond Recognition: Grau's 100-Day Government 76

5 Sugar and the Anglo-Cuban Commercial Treaty 98

6 The Second World War: Sugar without Cigars 117

7 Cold War: Democracy to Dictatorship 131

8 Revolution: Anglo-American Cooperation 154

9 Shipping, the Missile Crisis and Buses 178

$\begin{array}{ll}\text { Conclusion } & 201\end{array}$

$\begin{array}{lr}\text { Notes } & 214\end{array}$

$\begin{array}{ll}\text { Bibliography } & 264\end{array}$

$\begin{array}{lr}\text { Index } & 280\end{array}$ 


\section{List of Tables and Illustration}

\section{Table}

1 British diplomats in Havana, 1898-1964 7

2 Comparison of Cuban trade with the US and the UK 59

3 Anglo-Cuban trade, 1902-57 156

4 Anglo-Cuban trade, 1959-64 206

\section{Illustration}

1 'El León y Androcles', René de la Nuez, Revolución (Havana), 6 Oct. 1962 


\section{Acknowledgements}

A bursary from the School of Cultures, Languages and Area Studies at the University of Nottingham enabled me to undertake the research on which this book is based. I am also grateful to the Society of Latin American Studies (UK) for funding a six-week research trip to Cuba. Membership of the Centre for Research on Cuba at Nottingham provided me with various opportunities to disseminate my work and receive the feedback and support of others working in the field of Cuban studies.

The expert guidance and encouragement I received from Antoni Kapcia in the Department of Spanish, Portuguese and Latin American Studies at the University of Nottingham helped me greatly in completing this book. I am also grateful to John W. Young and Gareth Stockey at Nottingham for their valuable advice and to the late Jerry Hagelberg for reading Chapter 5 and giving me his expert feedback on the Cuban sugar industry and economy. I remain most thankful for the valuable research guidance I received in Cuba from Jorge Ibarra Guitart, Francisca López Civeira and Sonia Enjamio.

Without the generous hospitality of family and friends in London I would not have been able to carry out research for extended periods at the National Archives in Kew Gardens. I therefore owe thanks to my brother Robert and his partner Jane, Anthony and Anjli Carlucci, and Iona Keen.

I gratefully acknowledge two publishers for allowing me to reproduce extracts from the following articles: Taylor \& Francis - 'Our Arms in Havana: British Military Sales to Batista and Castro, 1958-59', Diplomacy \& Statecraft, 18.3 (2007), and 'Parallel Spheres: Anglo-American Cooperation over Cuba, 1959-61', Cold War History, 12.1 (2012); John Wiley and Sons - "Going to War in Buses": The Anglo-American Clash over Leyland Sales to Cuba, 1963-64', Diplomatic History, 34.5 (2010).

I am grateful to René de la Nuez for his kind permission to reproduce his political cartoon 'El León y Androcles' from October 1962. I thank both the Trustees of the Harold Macmillan Book Trust for their kind permission to quote from the prime minister's diaries, and the Selwyn Lloyd 
Trustees for their kind permission to quote from the Foreign Secretary's diaries. I also thank David Higham literary agents for their kind permission to cite from Graham Greene's screenplay for Our Man in Havana (Columbia Pictures, 1959), based on his novel of the same title.

My last words of gratitude go to my late father Oswald Hull. His lifelong interest in history and research evidently rubbed off on me, and I dedicate this book to his memory. 


\section{List of Abbreviations}

$\begin{array}{ll}\text { BT } & \text { Board of Trade } \\ \text { CAB } & \text { Cabinet Office } \\ \text { CoCom } & \text { Coordinating Committee on Export Controls } \\ \text { CO } & \text { Colonial Office } \\ \text { ECGD } & \text { Export Credits Guarantee Department } \\ \text { EEC } & \text { European Economic Community } \\ \text { FO } & \text { Foreign Office } \\ \text { HMG } & \text { Her/His Majesty's Government } \\ \text { m-fn } & \text { Most-favoured nation } \\ \text { PRO } & \text { Public Record Office } \\ \text { RAF } & \text { Royal Air Force } \\ \text { SIS } & \text { Secret Intelligence Service } \\ \text { T } & \text { Treasury } \\ \text { TNA } & \text { The National Archives of the UK }\end{array}$

